Postgraduate Bosowa University Publishing (PBUP)
Indonesian Journal of Business and Management
e-ISSN: $2460-3767 \quad p$-ISSN: $2656-6885$
Pttps://postgraduate.universitasbosowa.ac.id/index.php/jbm

\title{
PENGARUH ETIKA PROFESI, KOMPETENSI DAN KERJA SAMA TIM APARAT PENGAWAS INTERN PEMERINTAH (APIP) TERHADAP KUALITAS LAPORAN HASIL PENGAWASAN PADA KANTOR INSPEKTORAT DAERAH KABUPATEN PINRANG
}

\author{
The Influence Of Professional Ethics, Competence And Cooperation Of The Government Internal Supervisory \\ Author's Team (Apip) On The Quality Of Supervision Results At The Regional Inspectorate Office Of Pinrang \\ Regency \\ Irmayanti $^{1}$, Oesman Lewangka ${ }^{2}$, Sukmawati Mardjuni ${ }^{2}$ \\ ${ }^{1}$ Kementerian Agama Kabupaten Pinrang \\ ${ }^{2}$ Program Studi Manajemen Program Pascasarjana Universitas Bosowa \\ Email: irmayantinatsir88@gmail.com
}

Diterima: 20 September 2021/Disetujui: 24 Desember 2021

\begin{abstract}
ABSTRAK
Penelitian ini bertujuan untuk mengetahui dan menganalisis pengaruh Etika Profesi, Kompetensi dan Kerjasama Tim APIP pada kualitas Laporan Hasil Pengawasan. Untuk mencapai tujuan tersebut maka digunakan teknik pengumpulan data melalui penyebaran kuesioner, dengan teknik analisis data menggunakan analisis regresi berganda. Hasil penelitian menemukan bahwa Etika Profesi memberikan pengaruh yang bermakna dalam Kualitas Laporan Hasil Pengawasan, Kompetensi memberikan pengaruh yang bermakna dalam Kualitas Laporan Hasil Pengawasan serta Kerjasama Tim memberikan pengaruh positif terhadap Kualitas Laporan Hasil Pengawasan pada BKPSDM Kantor Inspektorat Daerah Kabupaten Pinrang Provinsi Sulawesi Selatan.
\end{abstract}

Kata Kunci: Etika Profesi, kompetensi, Kerjas sama Tim, Kualitas Laporan Hasil Pengawasan

\begin{abstract}
This study aims to determine and analyze the effect of Professional Ethics, Competence and Teamwork of APIP on the quality of the Supervision Report. To achieve this goal, data collection techniques were used through the distribution of questionnaires, with data analysis techniques using multiple regression analysis. The results of the study found that Professional Ethics had a significant influence on the Quality of Supervision Reports, Competence had a significant influence on the Quality of Supervision Reports and Teamwork had a positive influence on the Quality of Supervision Reports at the BKPSDM Regional Inspectorate Office, Pinrang Regency, South Sulawesi Province.
\end{abstract}

Keywords: Professional Ethics, Competence, Teamwork, Quality of Supervision Reports

This work is licensed under Creative Commons Attribution License 4.0 CC-BY International license

\section{PENDAHULUAN}

Tuntutan pemerintahan yang bersih, adil, transparan, dan akuntabel dari masyarakat harus disikapi dengan serius dan sistematis oleh penyelenggara negara, baik dalam tatanan eksekutif, legislatif, dan yudikatif bersamasama harus memiliki komitmen untuk menegakkan good governance dan clean government.

Dengan adanya komitmen pemerintah untuk mewujudkan good governance maka kinerja atas penyelenggaraan organisasi pemerintah menjadi perhatian pemerintah untuk dibenahi, salah satunya melalui sistem pengawasan yang efektif, dengan meningkatkan peran dan fungsi dari Aparat Pengawas Intern Pemerintah (APIP). Pengawasan intern adalah seluruh proses kegiatan audit, reviu, evaluasi, pemantauan, dan kegiatan pengawasan lain terhadap penyelenggaraan tugas dan fungsi organisasi dalam rangka memberikan keyakinan yang memadai bahwa kegiatan telah dilaksanakan sesuai dengan tolok ukur yang telah ditetapkan secara efektif dan 
efisien untuk kepentingan pimpinan dalam Mewujudkan tata kepemerintahan yang baik.

Peran APIP untuk mendorong peningkatan efektivitas manajemen risiko (risk management), pengendalian (control) dan tata kelola (governance) organisasi serta melakukan pembinaan Sistem Pengendalian Intern Pemerintah (SPIP) sebagaimana diamanatkan dalam Peraturan Pemerintah Nomor 60 Tahun 2008 tentang Sistem Pengendalian Intern Pemerintah. Peran Inspektorat Daerah sebagai Aparat Pengawasan Internal Pemerintah (APIP), Inspektorat Daerah memiliki peran dan posisi yang sangat strategis baik ditinjau dari aspek fungsi-fungsi manajemen maupun dari segi pencapaian visi dan misi serta program-program pemerintah.

Dari segi fungsi-fungsi dasar manajemen, Inspektorat daerah mempunyai kedudukan yang setara dengan fungsi perencanaan atau fungsi pelaksanaan. Sedangkan dari segi pencapaian visi, misi dan programprogram pemerintah, Inspektorat Daerah menjadi pilar yang bertugas sebagai pengawas sekaligus pengawal dalam pelaksanaan program yang tertuang dalam Anggaran Pendapatan dan Belanja Daerah.

Auditor dituntut untuk bekerja sesuai standart audit yang telah ditetapkan. Tidak boleh dipengaruhi oleh klien atau pendapat praktisi lain (Suraida 2005). Auditor disarankan meminta pendapat auditor senior jika pemahaman auditor belum cukup atas suatu kasus. Tanggung jawab auditor kepada publik untuk mendapatkan kualitas laporan hasil Pengawasan yang baik meskipun harus mengorbankan kepentingan pribadi (Pratiwi dan Nuryantoro 2015).

Kompetensi adalah suatu hal yang dikaitkan dengan kemampuan, pengetahuan/wawasan dan sikap yang dijadikan suatu pedoman dalam melakukan tanggung jawab pekerjaan yang dikerjakan oleh pegawai.

Kerjasama merupakan sinergitas kekuatan dari beberapa orang dalam mencapai satu tujuan yang diinginkan bersama. Kerjasama tim adalah keterlibatan beberapa orang dalam berkontribusi melaksanakan tugas dari organisasi guna mencapai visi misi organisasi dan mempersembahkan hasil bersama yang optimal.

Menurut Kreitner dan Angelo (2014, hal 45), kerjasama adalah orang-orang yang bekerjasama saat usaha mereka secara sistematis digabungkan untuk mencapai tujuan bersama.

Dari beberapa peneliti sebelumnya yang telah dikemukakan serta permasalahan yang ada, maka penulis perlu membuat sesuai kerangka berpikir. Tujuannya adalah, untuk memberikan kemudahan dalam mengkaji kondisi yang diteliti. Adapun kerangka berpikir dalam penelitian ini Pengaruh Etika Profesi, Kompetensi, Kerjasama Tim Terhadap Kualitas Laporan Hasil Pengawasan secara parsial dan simultan.

Laporan Hasil Pengawasan APIP merupakan sarana komunikasi yang resmi dan sangat penting untuk menyampaikan informasi tentang temuan, kesimpulan, dan rekomendasi kepada auditi atau pihak-pihak yang memerlukan informasi. Laporan dibuat berdasarkan kertas kerja pengawasan dan temuan hasil yang disusun selama melaksanakan pengawasan agar informasinya akurat dan obyektif.

\section{METODE}

\section{a. Jenis Penelitian}

Pendekatan penelitian yang akan digunakan dalam penelitian ini adalah pendekatan kuantitatif yang bersifat asosiatif. Pendekatan penelitian menggunakan jenis data kuantitatif yang didasari oleh pengujian teori yang disusun dari berbagai variabel, pengukuran yang melibatkan angka- angka dan dianalisa dengan menggunakan prosedur statistik. Metode asosiatif menurut Sugiyono (2010, hal 55) adalah sebagai berikut: "Penelitian asosiatif merupakan penelitian yang bertujuan untuk mengetahui hubungan dua variabel atau lebih. Dalam penelitian ini maka akan dapat dibangun suatu teori yang dapat berfungsi untuk menjelaskan, meramalkan dan mengontrol suatu gejala." Dalam penelitian ini, metode asosiatif digunakan untuk memberikan bukti empiris dan menganalisis tentang Etika Profesi, Kompetensi serta Kerjasama Tim sebagai variabel independen dan kualitas laporan hasil pemeriksaan Aparat Pengawas Insternal Pemerintah sebagai variabel dependen di Pinrang.

\section{b. Populasi dan Sampel}

Uma (2006) mengungkapkan populasi adalah keseluruhan objek penelitian. Sampel adalah subkelompok atau sebagian dari populasi. Sampel mewakili keseluruhan populasi yang ada. Dari sampel tersebut, akan mempermudah dalam melakukan analisis dan mendapatkan kesimpulan. Populasi dalam penelitian ini meliputi seluruh APIP yang bekerja pada Inspektorat Kabupaten Pinrang yang berjumlah 63 orang.

Teknik yang digunakan dalam pengambilan sampel adalah teknik pemilihan sampel dengan cara purposive sampling yaitu menentukan sampel dengan kriteria tertentu. Kriteria responden APIP dari Inspektorat Kabupaten Pinrang yang dijadikan sampel dalam penelitian ini adalah sebagai berikut:

1) Usia APIP (dibawah 30 tahun - diatas 40 tahun)

2) Jenis Kelamin APIP (Laki-laki dan Perempuan)

3) Jenjang pendidikan APIP (SMA-S2)

4) Lama bekerja APIP (dibawah 10 tahun - diatas 20 tahun)

Pemberian kriteria ini bertujuan agar pernyataan yang terdapat dalam kuisioner penelitian diisi oleh responden dengan tepat

\section{c. Variabel Penelitian}

Pada penelitian ini terdapat tiga macam variabel, yaitu variabel terikat (variabel dependen) merupakan variabel yang tergantung dengan variabel yang lainnya dan variabel bebas (variabel independen) merupakan variabel yang tidak memiliki ketergantungan terhadap 
variabel yang lainnya. serta variabel mediasi. Variabel yang digunakan dalam penelitian ini antara lain:

1) Variabel Independen (X)

Variabel independen atau variabel bebas merupakan variabel yang mempengaruhi atau menjadi sebab perubahan atau timbulnya variabel dependen (terikat). Variabel independen dalam penelitian ini adalah Etika Profesi (X1) Kompetensi (X2) serta Kerjasama Tim (X3).

2) Variabel Dependen (Y)

Variabel dependen atau variabel terikat merupakan variabel yang dipengaruhi atau yang menjadi akibat karena adanya variabel bebas. Variabel dependen dalam penelitian ini adalah kualitas laporan Hasi Pengawasan (Y)

\section{d. Jenis dan Sumber Data}

Adapun jenis data yang digunakan dalam penelitian ini adalah sebagai berikut:

1) Data kuantitatif, yaitu data yang diperoleh dari Kantor Inspektorat Daerah Kabupaten Pinrang dalam bentuk angka-angka yang masih perlu dianalisis kembali, seperti: jumlah pegawai, serta data lainnya yang menunjang pembahasan ini.

2) Data kualitatif, yaitu data yang diperoleh dari Kantor Inspektorat Daerah Kabupaten Pinrang dalam bentuk informasi baik secara lisan maupun tulisan, yang berperan sebagai data pendukung dalam penyusunan tesis ini, misalnya profil Kantor Inspektorat Daerah Kabupaten Pinrang, struktur organisasi serta data lainnya yang menunjang pokok pembahasan.

Sumber data yang digunakan dalam penelitian ini adalah:

1) Data Primer, yaitu data yang diperoleh dari tanggapan responden terhadap item pertanyaan yang diajukan dalam kuesioner.

2) Data Sekunder, yaitu data yang diperoleh dari dokumen-dokumen dan arsip Kantor Inspektorat Daerah Kabupaten Pinrang Provinsi Sulawesi Selatan yang ada kaitannya dengan penelitian ini.

\section{e. Teknik Pengumpulan Data}

Pada penelitian ini teknik pengumpulan data yang digunakan yaitu dengan menggunakan wawancara dan kuisioner.

1) Wawancara

Wawancara, dilakukan untuk mengetahui data dan masalah awal yang dijadikan acuan untuk melakukan penelitian. Adapun pihak yang diwawancarai adalah beberapa APIP Senior di Kantor Inspektorat Daerah Kabupaten Pinrang.

2) Kuesioner

Sugiyono (2010, hal 199) "Kuesioner merupakan teknik pengumpulan data yang dilakukan dengan cara memberi seperangkat pertanyaan atau pernyataan tertulis kepada responden untuk dijawabnya". Responden pada penelitian adalah APIP Senior di Kantor Inspektorat Daerah Kabupaten Pinrang yaitu berjumlah 63 orang yang dijadikan sebagai sampel penelitian.

\section{f. Teknis Analisis Data}

Berdasarkan permasalahan dan hipotesis yang telah dikemukakan sebelumnya, dalam menguji kebenarannya maka digunakan teknik analisis data yaitu sebagai berikut:

1) Analisis kualitatif adalah suatu analisis yang memberikan gambaran atau menguraikan mengenai jawaban-jawaban responden atas item-item yang terdapat dalam kuesioner dan akan diolah dengan cara dikelompokkan dan ditabulasikan kemudian diberi penjelasan.

2) Analisis Regresi Berganda yaitu suatu analisis untuk melihat seberapa besar pengaruh Etika Profesi, Kompetensi dan Kerjasama Tim terhadap Kualitas Laporan hasil Pengawasan degan persamaan yaitu :

$$
\mathrm{Y}=\mathrm{a}+\beta 1 \mathrm{X} 1+\beta 2 \mathrm{X} 2+\beta 3 \mathrm{X} 3+\mathrm{e}
$$

Dimana :

$\mathrm{Y}=$ Kualitas Laporan Hasil Pengawasan

$\mathrm{X}_{1} \quad=\quad$ Etika Profesi

$\mathrm{X}_{2}=$ Kompetensi

$\mathrm{X}_{3}=$ Kerjasama Tim

$\beta_{\mathrm{o}}=$ Konstanta

$\mathrm{e} \quad=$ Tingkat kesalahan

3) Uji Validitas dan Reliabilitas

Pengembangan instrument ditempuh melalui beberapa cara, yaitu selain mendefinisikan operasional variabel penelitian, menyusun indikator variabel penelitian dan melakukan uji coba instrument, dalam penelitian harus melakukan pengujian validitas dan reliabilitas.

a. Uji Validitas

Untuk menguji apakah instrumen yang dipakai cukup layak digunakan sehingga mampu menghasilkan data yang akurat sesuai petunjuk pengukurannya maka dilakukan uji validitas. Menurut Sugiyono (2010, hal 172), "Valid artinya data-data yang diperoleh dengan penggunaan alat (instrumen) dapat menjawab tujuan penelitian"

b. Uji Reliabilitas

Menurut Situmorang dan Lufti (2011, hal 79). "Reliabilitas adalah indeks yang menunjukkan sejauh mana suatu alat pengukur dapat dipercaya atau dapat didandalkan". Butir pertanyaan yang sudah dinyatakan valid dalam ujian validitas ditentukan reliabilitasnya dengan kriteria sebagai berikut:

1) Jika positif atau lebih besar dari a maka pertanyaan reliable

2) Jika negatif atau lebih kecil dari a maka pertanyaan tidak reliabel.

Jika nilai koefisien alpha lebih besar dari 0,6 maka disimpulkan bahwa instrument penelitan tersebut handal atau reliable.

4. Uji Asumsi klasik

Uji asumsi klasik bertujuan untuk menguji apakah model regresi linear bebas dari adanya bias atau penyimpangan sehingga diperoleh regresi yang benar BLUE (Best Linier Unbiased Estimation), yang terdiri dari: 
a. Uji Multikolineritas

Hasil uji multikolineritas menunjukkan besarnya nilai tolerance untuk semua variabel $>$ 0,1 dan nilai VIF masing-masing variabel $<10$ maka tidak terjadi multikolineritas.

b. Uji Heterokesdastisitas

Pengujian heterokesdastisitas dalam penelitian ini dilakukan dengan Glejser Test dengan pvalue masing-masing > 0,05, maka model regresi tidak terjadi heterokesdastisitas.

c. Uji Normalitas

Pengujian normalitas dapat dilakukan dengan uji kosmogorov-smirnov test, hasil pengujian menunjukkan bahwa apabila pvalue atau signifikan > nilai standar, maka data residual berdistribusi normal.

5. Uji Hipotesis

a. $\quad$ Uji T (Uji parsial)

Uji ini adalah untuk mengetahui apakah pengaruh masing-masing variabel bebas terhadap variabel terikat bermakna atau tidak, pengujian ini dilakukan dengan membandingkan antara nilai $\mathrm{t}_{\text {hitung }}$ masingmasing variabel bebas dengan nilai $t_{\text {tabel }}$ dengan derajat kesalahan $5 \%(\alpha=0.05)$. Apabila nilai $t_{\text {hitung }} \geq t_{\text {tabel }}$, maka variabel bebasnya memberikan pengaruh bermakna terhadap variabel terikat.

b. Uji F (Uji Simultan)

Uji ini digunakan untuk mengetahui apakah seluruh variabel bebasnya secara bersama-sama mempunyai pengaruh yang bermakna terhadap variabel terikat. Pengujian dilakukan dengan membandingkan nilai $\mathrm{F}_{\text {hitung }}$ dengan $\mathrm{F}_{\text {tabel }}$ pada derajat kesalahan $5 \%(\alpha=0.05)$. Apabila nilai $\mathrm{F}_{\text {hitung }} \geq$ dari nilai $\mathrm{F}_{\text {tabel }}$, maka berarti variabel bebasnya secara bersama-sama memberikan pengaruh yang bermakna terhadap variabel terikat. Dengan menggunakan alat bantu program SPSS versi 26.

6. Koefisien Determinasi $\left(\mathrm{R}^{2}\right)$

Koefisien determinasi $\left(\mathrm{R}^{2}\right)$ dimaksudkan untuk mengetahui tingkat ketepatan paling baik dalam analisa regresi dimana hal yang ditunjukan oleh besarnya koefisien determinasi $\left(\mathrm{R}^{2}\right)$ antara 0 (nol) dan I (satu). Koefsien determinasi $\left(\mathrm{R}^{2}\right)$ nol variabel independen sama sekali tidak berpengaruh terhadap variabel dependen. Apabila koefisien determinasi semakin mendekati satu, maka dapat dikatakan bahwa variabel independen berpengaruh terhadap variabel dependen

\section{HASIL DAN PEMBAHASAN}

\section{a. Karakteristik Responden Penelitian}

a. Uji Validitas

Uji validitas (uji kesahihan) adalah suatu alat yang digunakan untuk mengukur sah/valid tidaknya kuesioner.
Uji validitas dilakukan dengan cara menguji kolerasi antara skor item dengan skor total masing- masing variabel, menggunakan pearson corelation. Butir pertanyaan dikatakan valid apabila tingkat signifikannya dibawah 0,05.

Berdasarkan hasil pengujian validitas terhadap setiap instrument variabel, maka dapat diperoleh hasil uji validitas sebagai berikut :

Tabel 1

Hasil Uji Validitas Etika Profesi

\begin{tabular}{|c|c|c|c|c|c|}
\hline & $\begin{array}{c}\text { Butir } \\
\text { Pertanyaan }\end{array}$ & $\begin{array}{l}\text { Pearson Corelation } \\
\text { (r hitung) }\end{array}$ & $\mathrm{r}$ tabel & $\begin{array}{l}\text { Sig (2- } \\
\text { Tailed) }\end{array}$ & $\begin{array}{c}\text { Keterang } \\
\text { an }\end{array}$ \\
\hline \multirow{10}{*}{$\begin{array}{l}X \\
1\end{array}$} & EP.1 & $0,552 * *$ & \multirow{10}{*}{0.3173} & 0,000 & Valid \\
\hline & EP.2 & $0,632 * *$ & & 0,000 & Valid \\
\hline & EP.3 & $0,631 * *$ & & 0,000 & Valid \\
\hline & EP. 4 & $0,621 * *$ & & 0,000 & Valid \\
\hline & EP. 5 & $0,679 * *$ & & 0,000 & Valid \\
\hline & EP. 6 & $0,499 * *$ & & 0,000 & Valid \\
\hline & EP. 7 & $0,626 * *$ & & 0,000 & Valid \\
\hline & EP. 8 & $0,672 * *$ & & 0,000 & Valid \\
\hline & EP. 9 & $0,656 * *$ & & 0,000 & Valid \\
\hline & EP. 10 & $0,702 * *$ & & 0,000 & Valid \\
\hline
\end{tabular}

Sumber :Data Primer (kuesioner), diolah dengan SPSS (2021)

Dari Tabel 1. di atas dapat dilihat uji validitas Etika Profesi menunjukan dari 10 item pernyataan seluruhnya dinyatakan valid karena nilai rhitung > rtabel dan nilai signifikan $<0,05$.. Dengan demikian 10 item penyataan dari veriabel kompetensi dapat dilanjutkan kepada pengujian reabilitas instrument.

Tabel 2

Hasil Uji Validitas Kompetensi

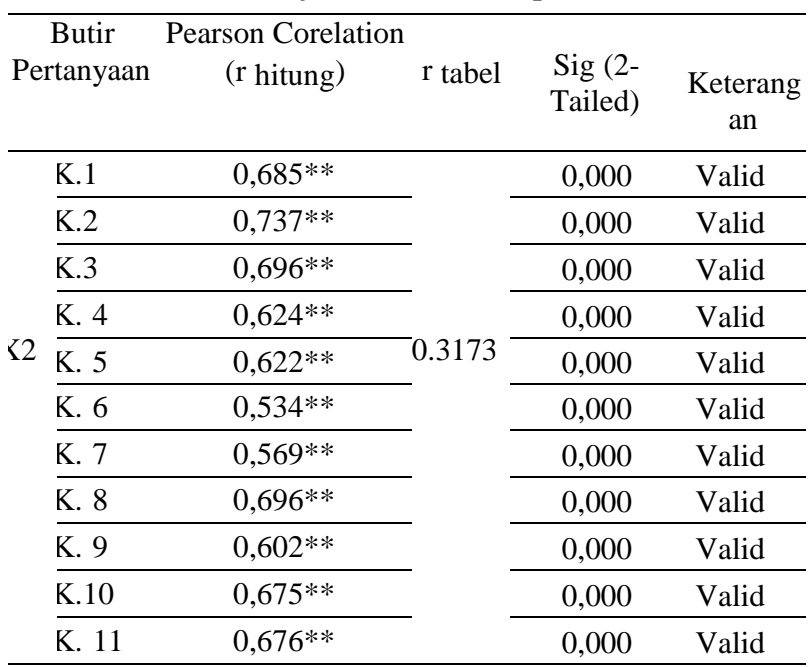

Sumber :Data Primer (kuesioner), diolah dengan SPSS (2021)

Dari Tabel 2. di atas dapat dilihat uji validitas Kompetensi menunjukan dari 11 item pernyataan seluruhnya dinyatakan valid karena nilai rhitung > rtabel dan nilai signifikan $<0,05$. Dengan demikian 11 item 
penyataan dari veriabel kompetensi dapat dilanjutkan kepada pengujian reabilitas instrument

Tabel 3

Hasil Uji Validitas Kerja Sama Tim

\begin{tabular}{|c|c|c|c|c|c|}
\hline \multicolumn{2}{|c|}{$\begin{array}{l}\text { Butir } \\
\text { Pertanyaan }\end{array}$} & $\begin{array}{c}\text { Pearson } \\
\text { Corelation }\end{array}$ & \multirow[t]{2}{*}{$\mathrm{r}$ tabel } & $\begin{array}{l}\text { Sig (2- } \\
\text { Tailed) }\end{array}$ & \multirow{2}{*}{ 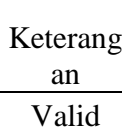 } \\
\hline & KT.1 & $0,602 * *$ & & 0,000 & \\
\hline & KT..2 & $0,611 * *$ & \multirow{8}{*}{0.3173} & 0,000 & Valid \\
\hline & KT..3 & $0,603 * *$ & & 0,000 & Valid \\
\hline$X$ & KT .4 & $0,608 * *$ & & 0,000 & Valid \\
\hline 3 & KT..5 & $0,551 * *$ & & 0,000 & Valid \\
\hline & KT..6 & $0,710 * *$ & & 0,000 & Valid \\
\hline & KT.7 & $0,578 * *$ & & 0,000 & Valid \\
\hline & KT.8 & $0,702 * *$ & & 0,000 & Valid \\
\hline & KT.9 & $0,482 * *$ & & 0,000 & Valid \\
\hline
\end{tabular}

Sumber :Data Primer (kuesioner), diolah dengan SPSS (2021)

Dari Tabel 3. di atas dapat dilihat uji validitas Kerjasama Tim menunjukan dari 9 item pernyataan seluruhnya dinyatakan valid karena nilai rhitung > rtabel dan nilai signifikan $<0,05$.. Dengan demikian 9 item penyataan dari veriabel Kerjasama Tim dapat dilanjutkan kepada pengujian reabilitas instrument.

Tabel 4.

Hasil Uji Validitas Kualitas Laporan Hasil Pengawsan

\begin{tabular}{|c|c|c|c|c|c|}
\hline \multicolumn{2}{|c|}{ Butir Pertanyaan } & \multirow{2}{*}{\multicolumn{2}{|c|}{$\begin{array}{l}\text { Pearson } \\
\text { Corelation } \\
(\mathrm{r} \text { hitung) } \quad \mathrm{r} \text { tabel }\end{array}$}} & \multirow{2}{*}{$\begin{array}{l}\text { Sig (2- } \\
\text { Tailed) } \\
0,000\end{array}$} & \multirow{2}{*}{$\begin{array}{c}\text { Keterangan } \\
\text { Valid }\end{array}$} \\
\hline \multirow{13}{*}{$\mathrm{Y}$} & KHLP.1 & & & & \\
\hline & KHLP .2 & $0,643 * *$ & \multirow{12}{*}{0.3173} & 0,000 & Valid \\
\hline & KHLP .3 & $0,621 * *$ & & 0,000 & Valid \\
\hline & KHLP .4 & $0,614 * *$ & & 0,000 & Valid \\
\hline & KHLP .5 & $0,575 * *$ & & 0,000 & Valid \\
\hline & KHLP .6 & $0,535^{* *}$ & & 0,000 & Valid \\
\hline & KHLP .7 & $0,462 * *$ & & 0,000 & Valid \\
\hline & KHLP .8 & $0,641 * *$ & & 0,000 & Valid \\
\hline & KHLP .9 & $0,413 * *$ & & 0,000 & Valid \\
\hline & KHLP .10 & $0,469 * *$ & & 0,000 & Valid \\
\hline & KHLP .11 & $0,428 * *$ & & 0,000 & Valid \\
\hline & KHLP .12 & $0,443 * *$ & & 0,000 & Valid \\
\hline & KHLP .13 & $0,440 * *$ & & 0,000 & Valid \\
\hline
\end{tabular}

Sumber :Data Primer (kuesioner), diolah dengan SPSS (2021)

Dari Tabel 4. di atas dapat dilihat uji validitas Kualitas Laporan Hasil Pengawsan menunjukan dari 13 item pernyataan seluruhnya dinyatakan valid karena nilai rhitung $>$ rtabel dan nilai signifikan $<0,05$. Dengan demikian 13 item penyataan dari veriabel Kualitas Laporan Hasil Pengawsan dapat dilanjutkan kepada pengujian reabilitas instrument.

\section{b. Uji Reabilitas}

Uji reliabilitas adalah alat untuk mengukur suatu kuesioner yang merupakan indikator dari variabel atau konstruk. Uji reliabilitas ini dilakukan untuk menguji konsistensi jawaban dari responden melalui pertanyaan yang diberikan, menggunakan metode statistik Cronbach Alpha dengan signifikansi yang digunakan lebih dari (>) 0,6. Adapun hasil dari pengujian reliabilitas adalah sebagai berikut:

Tabel 5 Hasil Uji Reliabilitas

\begin{tabular}{lccc}
\hline \multicolumn{1}{c}{ Variabel } & $\begin{array}{c}\text { Cronbach's } \\
\text { Alpha }\end{array}$ & $\begin{array}{c}\text { Standar } \\
\text { Reliabilitas }\end{array}$ & Ket. \\
\hline Etika profesi (X1) & 0.847 & 0,60 & Reliabel \\
\hline kompetensi (X2) & 0.883 & 0,60 & Reliabel \\
\hline Kerjasama Tim (X3) & 0.802 & 0,60 & Reliabel \\
\hline $\begin{array}{l}\text { Kualitas Hasil Laporan } \\
\text { Pengawasan (Y) }\end{array}$ & 0.783 & 0,60 & Reliabel \\
\hline $\begin{array}{l}\text { Sumber :Data Primer (kuesioner), diolah dengan SPSS (2021) } \\
\text { Sul }\end{array}$
\end{tabular}

\section{c. Uji Normalitas}

Dalam penelitian ini untuk menguji normalitas data digunakan one sample Kolmogorov-smirnov yang hasil pengujiannya dapat dilihat pada gambar di bawah ini:

Tabel 6 Hasil Uji Normalitas

One-Sample Kolmogorov-Smirnov Test

Unstandardized Residual

\begin{tabular}{llr}
\hline $\mathrm{N}$ & & .0000000 \\
\hline Normal & Mean & .25073175 \\
\cline { 2 - 3 } Parameters & Std. Deviation & .102 \\
\hline Most & Absolute & .102 \\
\cline { 2 - 3 } Extreme & Positive & -.086 \\
\cline { 2 - 3 } Differences & Negative & .812 \\
\hline Kolmogorov-Smirnov Z & .524 \\
\hline Asymp. Sig. (2-tailed) & \\
\hline a. Test distribution is Normal. & \\
b. Calculated from data. & \\
Sumber : Data yang diolah, 2021 &
\end{tabular}

Berdasarkan Tabel 6 terlihat bahwa nilai sig yang diperoleh lebih dari 0,05. Hal ini menunjukkan bahwa model regresi layak dipakai karena memenuhi asumsi Normalitas.

\section{d. Uji Heteroskedastisitas}

Hasil pengujian multikolinieritas dapat dilihat pada tabel berikut ini:

Tabel 7. Hasil Uji Multikolineritas Coefficientsa

\begin{tabular}{llll}
\hline \multirow{2}{*}{ Model } & \multicolumn{2}{c}{ Collinearity Statistics } \\
\cline { 2 - 4 } & \multicolumn{2}{c}{ Tolerance } & \multicolumn{1}{c}{ VIF } \\
\hline \multirow{2}{*}{1 Constant) } & & \\
\cline { 2 - 4 } 1 & Etika Profesi & .640 & 1.564 \\
\cline { 2 - 4 } & Kualitas Kompetensi & .855 & 1.169 \\
\cline { 2 - 4 } & Kerjasama Tim & .708 & 1.412 \\
\hline Sumber : Data yang diolah, 2021 & &
\end{tabular}

Sumber : Data yang diolah, 2021

Berdasarkan Tabel 7, terlihat bahwa variabel etika profesi, kompetensi, Kerjasama tim memiliki nilai tolerance diatas 0,1 dan VIF lebih kecil dari 10. Hal ini berari dalam model persamaan regresi tidak terdapat 
Pengaruh Etika Profesi, Kompetensi dan Kerjasama.... (Irmayanti, Oesman Lewangka, Sukmawati Mardjuni)

gejala multikolonearitas sehingga data dapat digunakan dalam penelitian ini.

Hasil pengujian heteroskedastisitas dapat dilihat pada gambar di bawah ini:

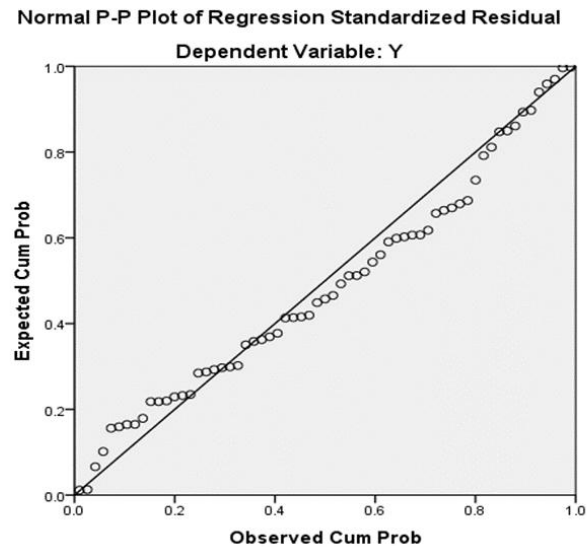

Gambar 1.Hasil Uji Heteroskedastisitas Pada Diagram Scatterplot

Sumber Data Primer (Kuesioner). Diolah (2021)

Berdasarkan gambar 1 grafik scatterplot menunjukkan bahwa data tersebar pada sumbu $\mathrm{Y}$ dan tidak membentuk suatu pola yang jelas dalam penyebaran data tersebut. Hal ini menunjukkan bahwa tidak terjadi heterokedaktisitas pada model regresi tersebut, sehingga model regresi layak digunakan untuk memprediksi kualitas laporan hasil pengawasan dengan variabel yang mempengaruhi yaitu etika profesi, kompetensi, Kerjasama tim

\section{e. Analisis Regresi Linear Berganda}

Analisis Regresi Berganda bertujuan untuk mengetahui pengaruh Etika Profesi, Kompetensi dan Kerjasama Tim terhadap Kualitas Laporan Hasil Pengawasan pada Kantor Inspektorat Daerah Kabupaten Pinrang Provinsi Sulawesi Selatan, dimana dalam pelaksanaan analisis uji dalam penelitian ini dilakukan dengan melakukan penyebaran kuesioner kepada pegawai dengan membagikan kuesioner kepada 63 orang pegawai pada Kantor Inspektorat Daerah Kabupaten Pinrang Provinsi Sulawesi Selatan.

Berdasarkan hasil olahan data dalam penelitian ini dengan menggunakan SPSS Versi 26, sebelum dilakukan analisis pengaruh langsung dalam penelitian ini maka akan disajikan hasil koefisien jalur dari setiap variabel dalam penelitian ini yakni pengaruh Etika Profesi, Kompetensi dan Kerjasama Tim terhadap Kualitas Laporan Hasil Pengawasan pada Kantor Inspektorat Daerah Kabupaten Pinrang (model 1), yang dapat disajikan melalui tabel berikut ini:
Tabel 8. Hasil Uji Regresi Linear Berganda

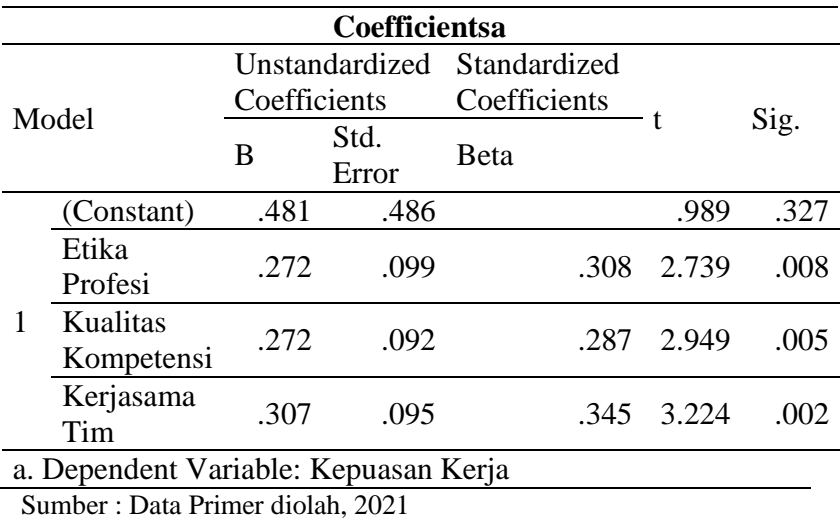

Berdasarkan hasil olahan data yang sebagaimana telah disajikan melalui tabel 1 maka dapat disajikan persamaan regresi dalam penelitian ini yang dapat diuraikan sebagai berikut

$\mathrm{Y}=0,481+0,2721+0,272 \mathrm{X} 2+0,307 \mathrm{X} 3$

Dari persamaan di atas maka dapat diinterpretasikan atau dijelaskan dari persamaan regresi yang telah dikemukakan yaitu sebagai berikut :

a) Nilai konstanta adalah 0,481 ini menunjukkan bahwa, jika variabel etika profesi, kompetensi, Kerjasama tim, bernilai nol (0), maka nilai variabel dependen (kualitas laporan hasil pengawasan) sebesar 0,481 satuan.

b) Koefisien regresi etika profesi (X1) adalah 0,272 dan bertanda positif. Hal ini berarti, nilai variabel Y akan mengalami kenaikan sebesar 0, 272 jika nilai variabel X1 mengalami kenaikan satu satuan dan variabel independen lainnya bernilai tetap. Koefisien bertanda positif menunjukkan adanya hubungan yang searah antara variabel etika profesi (X1) dengan variabel kualitas laporan hasil pengawasan (Y). Semakin tinggi etika profesi maka kualitas laporan hasil pengawasan akan semakin meningkat.

c) Koefisien regresi kompetensi (X2) adalah 0,272 dan bertanda positif. Hal ini berarti, nilai variabel $Y$ akan mengalami kenaikan sebesar 0, 272 jika nilai variabel X2 mengalami kenaikan satu satuan dan variabel independen lainnya bernilai tetap. Koefisien bertanda positif menunjukkan adanya hubungan yang searah antara variabel kompetensi (X2) dengan variabel kualitas laporan hasil pengawasan (Y). Semakin tinggi kompetensi, maka kualitas laporan hasil pengawasan akan semakin meningkat.

d) Koefisien regresi Kerjasama tim (X3) adalah 0,307 dan bertanda positif. Hal ini berarti, nilai variabel Y akan mengalami kenaikan sebesar 0, 307 jika nilai variabel X3 mengalami kenaikan satu satuan dan variabel independen lainnya bernilai tetap. Koefisien bertanda positif menunjukkan adanya hubungan yang searah antara variabel Kerjasama tim (X3) dengan variabel kualitas laporan hasil pengawasan 
(Y). Semakin tinggi Kerjasama tim, maka kualitas laporan hasil pengawasan akan semakin meningkat Tabel 9. Hasil Uji t (Parsial)

\begin{tabular}{llll}
\hline \multicolumn{1}{c}{ Variabel } & $\mathrm{T}_{\text {hitung }}$ & $\mathrm{T}_{\text {Tabel }}$ & Sig. \\
\hline Etika profesi (X1) & 2.739 & 1.691 & .019 \\
\hline kompetensi (X2) & 2.949 & 1.691 & .048 \\
\hline Kerjasama tim (X3) & 3.224 & 1.691 & .019 \\
\hline
\end{tabular}

Tabel 10. Hasil Uji F (Simultan), ANOVA

\begin{tabular}{|c|c|c|c|c|c|c|}
\hline \multicolumn{2}{|c|}{ Model } & $\begin{array}{c}\text { Sum of } \\
\text { Squares }\end{array}$ & df & $\begin{array}{l}\text { Mean } \\
\text { Square }\end{array}$ & $\mathrm{F}$ & Sig. \\
\hline \multirow{3}{*}{1} & Regression & 4.266 & 3 & 1.422 & 21.527 & $.000^{\mathrm{b}}$ \\
\hline & Residual & 3.898 & 59 & .066 & & \\
\hline & Total & 8.164 & 62 & & & \\
\hline
\end{tabular}

Tabel 11. Hasil Koefisien Determinasi (R2) Model Summaryb

\begin{tabular}{lrrrrr}
\hline Model & $\mathrm{R}$ & $\begin{array}{c}\mathrm{R} \\
\text { Square }\end{array}$ & $\begin{array}{c}\text { Adjusted R } \\
\text { Square }\end{array}$ & $\begin{array}{l}\text { Std. Error of } \\
\text { the Estimate }\end{array}$ & $\begin{array}{l}\text { Durbin- } \\
\text { Watson }\end{array}$ \\
\hline 1 & $.723^{\mathrm{a}}$ & .523 & .498 & .25703 & 1.635
\end{tabular}

a. Predictors: (Constant), etika profesi, kompetensi, Kerjasama tim b. Dependent Variable: kualitas laporan hasil pengawasan

Sumber: Data Primer (Kuesioner), diolah dengan SPSS (2021

Dari tabel tersebut terdapat angka $\mathrm{R}$ sebesar 0,723 yang menunjukkan bahwa hubungan antara kualitas laporan hasil pengawasan dengan ketiga variabel independennya kuat, karena berada di defenisi kuat yang angkanya diatas $0,6-0,8$. Sedangkan nilai $\mathrm{R}$ square sebesar 0,523 atau $52,3 \%$ ini menunjukkan bahwa variabel kualitas laporan hasil pengawasan dapat dijelaskan oleh variabel etika profesi, kompetensi, Kerjasama tim sebesar 52,3\% sedangkan sisanya 47,7\% dapat dijelaskan dengan variabel lain yang tidak terdapat pada penelitian ini.

\section{2) Pengaruh Etika Profesi terhadap Kualitas LHP}

Dari hasil pengolahan data yang telah didapat pada variabel Etika Profesi terhadap Kualitas Laporan Hasil Pengawasan thitung $=2.739>\mathrm{t}$ tabel $=1,671$ dengan nilai signifikansi sebesar $=0,001<0,05$. Hal ini menunjukan bahwa Etika Profesi berpengaruh positif dan signifikan terhadap Kualitas Laporan Hasil Pengawasan. Dengan begitu dapat diartikan bahwa Etika Profesi yang meningkat akan berdampak pada peningkatan Kualitas Laporan Hasil Pengawasan di kantor Inspektorat Kabupaten Pinrang. Hal ini sesuai dengan realita yang beada di Kantor Inspektorat dimana masing-masing APIP harus mampu menjaga dan menerapkan Etika Profesi didalam Organisasi.

\section{3) Pengaruh Kompetensi terhadap Kualitas LHP}

Dari hasil pengolahan data yang telah didapat pada variabel kompetensi terhadap Kualitas Laporan Hasil Pengawasan thitung $=2.949>\mathrm{t}$ tabel $=1,671$ dengan nilai signifikansi sebesar $=0,001<0,05$. Hal ini menunjukan bahwa kompetensi berpengaruh positif dan signifikan terhadap Kualitas Laporan Hasil Pengawasan. Dengan begitu dapat diartikan bahwa kompetensi yang meningkat akan berdampak pada peningkatan Kualitas Laporan Hasil Pengawasan di kantor Inspektorat Kabupaten Pinrang. Hal ini sejalan dengan yang dilapangan, dimana APIP yang memiliki kompetensi akan dengan mudah menjalankan tanggungjawabnya.

\section{4) Pengaruh Kerjasama Tim terhadap Kualitas LHP}

Dari hasil pengolahan data yang telah didapat pada variabel Kerjasama Tim terhadap Kualitas Laporan Hasil Pengawasan thitung $=3.224>\mathrm{t}$ tabel $=1,671$ dengan nilai signifikansi sebesar $=0,001<0,05$. Hal ini menunjukan bahwa Kerjasama Tim berpengaruh positif dan signifikan terhadap Kualitas Laporan Hasil Pengawasan. Dengan begitu dapat diartikan bahwa Kerjasama Tim yang meningkat akan berdampak pada peningkatan Kualitas Laporan Hasil Pengawasan di kantor Inspektorat Kabupaten Pinrang. Pada fakta lapangan dimana pembentukan tim kerja yang solid akan mampu menghasilkan laporan hasil pengawasana yang berkualitas.

5) Pengaruh Etika profesi, Kompetensi dan Kerjasama Tim terhadap Kualitas Laporan Hasil Pengawasan

Dari hasil pengolahan data yang telah didapat pada Etika Profesi, Kompetensi dan Kerjasama Tim terhadap Kualitas Laporan Hasil Pengawasan, F hitung sebesar = $21.527>\mathrm{F}$ tabel $=2,76$ dengan nilai signifikansi sebesar $=0,000$. Hal ini menunjukan bahwa Etika Profesi, Kompetensi dan Kerjasama Tim secara simultan berpengaruh positif dan signifikan terhadap Kualitas Laporan Hasil Pengawasan. Dengan begitu dapat diartikan bahwa Etika Profesi, Kompetensi dan Kerjasama Tim yang meningkat akan berdampak pada peningkatan Kualitas Laporan Hasil Pengawasan di kantor Inspektorat Kabupaten Pinrang.

Berdasarkan hasil analisis regresi tersebut, yang telah diuraikan maka dapat dilihat melalui gambar yaitu sebagai berikut :

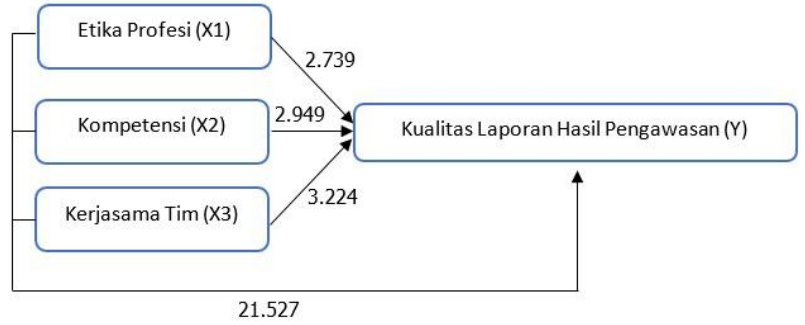

Gambar 2. Hasil Analisis Regresi Linear Berganda

\section{KESIMPULAN DAN SARAN}

Hasil penelitian dapat disimpulkan sebagai berikut: 
a. Etika Profesi berpengaruh positif dan signifikan terhadap Kualitas Laporan Hasil Pengawasan di Kantor Inspektorat Daerah Kabupaten Pinrang. Dengan begitu penerapan kode etik/ etika profesi yang meningkat akan berdampak pada Kualitas Laporan Hasil Pengawasan di Kantor Inspektorat Daerah Kabupaten Pinrang.

b. Kompetensi berpengaruh positif dan signifikan terhadap Kualitas Laporan Hasil Pengawasan di Kantor Inspektorat Daerah Kabupaten Pinrang. Dengan begitu peningkatan pengetahuan serta keterampilan APIP akan berdampak pada Kualitas Laporan Hasil Pengawasan di Kantor Inspektorat Daerah Kabupaten Pinrang.

c. Kerjasama Tim berpengaruh positif dan signifikan terhadap Kualitas Laporan Hasil Pengawasan di Kantor Inspektorat Daerah Kabupaten Pinrang. Kerjasama Tim Audit yang saling bersinergi dan berkontribusi pada masing-masing posisi akan berdampak pada Kualitas Laporan Hasil Pengawasan di Kantor Inspektorat Daerah Kabupaten Pinrang.

d. Etika Profesi, Kompetensi dan Kerjasama Tim secara simultan berpengaruh positif dan signifikan terhadap Kualitas Laporan Hasil Pengawasan di Kantor Inspektorat Daerah Kabupaten Pinrang. Seorang APIP yang professional akan terus menjaga etika, meningkatkan kompetensi serta membangun kerjasama tim dalam pengawasan yang berdampak positif terhadap laporan hasil pengawasannya di Kantor Inspektorat Daerah Kabupaten Pinrang.

\section{DAFTAR PUSTAKA}

Kreitner, Robert dan Angelo Kinicki. 2014. Perilaku Organisasi. Edisi 9. Buku 1. Jakarta: Salemba Empat.

Peraturan Pemerintah Nomor 60 Tahun 2008 tentang Sistem Pengendalian Intern Pemerintah.

Pratiwi, R. C. dan Nuryantoro. 2015. Pengaruh Independensi, Etika Profesi dan Kepuasan Kerja Auditor Terhadap Kualitas Audit (Studi pada Kantor Akuntan Publik di Wilayah Bandung). E-Proceeding of Management. Vol. 2 (3). Hal. 3206-3212.

Situmorang, Syafrizal Helmi dan Muslich Lutfi, 2011. Analisis Data Untuk Riset Manajemen Dan Bisnis. Edisi 2. Medan: USU Press.

Sugiyono. 2010. Metode Penelitian Pendidikan Pendekatan Kuantitatif, kualitatif, dan R\&D. Bandung: Alfabeta.

Suraida, Ida. 2005. Jurnal. Pengaruh Etika, Kompetensi, Pengalaman Audit dan Resiko Audit Terhadap Skeptisme Profesional Auditor dan Ketepatan Pemberian Opini Akuntan publik. Sosiohumaniora, Vol. 7, No. 3.

Uma Sekaran, 2006. Metode Penelitiaan Bisnis. Jakarta: Salemba Empat 